\begin{tabular}{llr} 
Jurnal Pendidikan Dasar Perkhasa & \\
http://jurnal.stkippersada.ac.id/jurnal/index.php/JPDP/ & P-ISSN 2461-078X \\
E-ISSN 2654-783X & & DoI : 10.31932/jpdp.v5i2.475 \\
\hline JPDP & (2) (2019) 121-132 & JPDP
\end{tabular}

\title{
PENERAPAN MODEL PEMBELAJARAN REFLECTIVE LEARNING UNTUK MENINGKATKAN KEDISIPLINAN DAN HASIL BELAJAR SISWA MATA PELAJARAN PKN KELAS 5 SDN SUKODONO 03
}

\author{
Suluh Prayogo* ${ }^{* 1}$, Firosalia Kristin ${ }^{2}$, Indri Anugraheni ${ }^{3}$ \\ 1,2,3Program Studi PGSD, Universitas Kristen Satya Wacana \\ Diterima: 12 September 2019. Dipublikasi: 28 Oktober 2019.
}

\begin{abstract}
This research aims to find out the steps of Reflective Learning model to improve the discipline and learning outcomes of PKn-grade 5 students of Sukodono Elementary School, Kab. Jepara. The research conducted is class action research (PTK) with the subject of Grade 5 students of Sukodono 03 Elementary School, totalling 23 students and performed in 2 cycles. The data collection techniques used are test techniques and non test techniques. The data analysis used is quantitative and qualitative descriptive analysis. Application with Reflektive learning model can improve discipline and outcome of learning Maple PKn theme 1 Sub theme 2 Grade 5 students elementary School Sukodono 03. This is evident in the occurrence of an average increase. Students ' discipline from the initial condition (pre-cycle) amounted to 50.43 with less disciplined criteria, after conducted research on cycle I to 88.40 with disciplinary criteria, and on the cycle II the average student creativity score increased to 96.73 With highly disciplined criteria. Student learning results have also increased with an average in the initial condition (pre-cycle) of 64.08 with a total of 7 students due to a percentage of 30.43 and 16 students are not finished with a percentage of 69.57. In cycle I experienced an increase with an average score of 85.86 with a total of 20 students finished with a percentage of 89.95 and 3 students did not complete with 13.05 percent. In cycle II also increased with an average score of 87.17 with a complete student count of 23 with a percentage of 100 .
\end{abstract}

Keywords: Reflective Learning Model, Discipline, Leaning Outcomes

Abstrak. Reflective Learning untuk meningkatkan kedisiplinan dan hasil belajar PKn siswa kelas 5 SD Negeri Sukodono, Kab. Jepara.Penelitian yang dilakukan adalah Penelitian Tindakan Kelas (PTK) dengan subjek siswa kelas 5 SD Negeri Sukodono 03 yang berjumlah 23 siswa dan dilakukan dalam 2 siklus. Teknik pengumpulan data yang digunakan berupa teknik tes dan teknik non tes. Analisis data yang digunakan adalah analisis deskriptif kuantitatif dan kualitatif. Penerapan dengan model Reflektive Learning dapat meningkatkan kedisiplinan dan hasil belajar mapel PKn Tema 1 Sub Tema 2 siswa kelas 5 SD Negeri Sukodono 03. Hal ini terbukti dengan terjadinya peningkatan rata-rata.Kedisplinan siswa dari kondisi awal (pra siklus) sebesar 50,43 dengan kriteria kurang disiplin, setelah dilakukan penelitian pada siklus I menjadi 88,40 dengan kriteria disiplin, dan pada siklus II skor rata-rata kreativitas siswa meningkat menjadi 96,73 dengan kriteria sangat disiplin. Hasil belajar siswa juga mengalami peningkatan dengan rata-rata pada kondisi awal (pra siklus) sebesar 64,08 dengan jumlah 7 siswa tuntas dengan persentase 30,43 dan 16 siswa tidak tuntas dengan persentase 69,57. Pada siklus I mengalami peningkatan dengan skor rata-rata sebesar 85,86 dengan jumlah 20 siswa tuntas dengan presentase 89,95 dan 3 siswa tidak tuntas dengan persentase 13,05. Pada siklus II juga mengalami peningkatan dengan skor rata-rata 87,17 dengan jumlah siswa yang tuntas sebanyak 23 dengan persentase 100 .

Kata kunci: Reflektive Learning, Kedisiplinan, Hasil Belajar 
S. Prayogo, F. Kristin, I. Anugraheni | JPDP 5 (2) Oktober 2019, 121-132

Pendahuluan

Pendidikan Kewarganegaraan merupakan pendidikan yang menyangkut status formal warga negara yang pada awalnya diatur dalam Undang-Undang No. 2 th. 2003 (Soemantri, 2011 : 167). PKn adalah pelajaran formal yang berupa sejarah masa lampau, perkembangan sosial budaya, perkembangan teknologi, tata cara hidup bersosial, serta peraturan kenegaraan. Luasnya materi PKn menyebabkan anak sulit untuk diajak berfikir kritis dan kreatif dalam menyikapi masalah yang berbeda sehingga kedisiplinan dan hasil belajar yang dihasilkan rendah.

Kedisiplinan berasal dari kata disiplin yang memiliki makna mengajari atau mengikuti pemimpin yang dihormati. Mustari (2014 : 56) berpendapat bahwa disiplin merujuk pada instruksi sitematis yang diberikan kepada murid. Sumantri (2010: 117-137) menuliskan Untuk mendisiplinkan berarti menginstruksikan orang untuk mengikuti tatanan tertentu melalui aturan-aturan tertentu. Dalam arti lain disiplin merupakan suatu ilmu tertentu yang diberikan kepada murid atau siswa. Hadianti L.S (2017: 1-8)
Disiplin dapat memberikan efek yang positif bagi siswa. Kedisiplinan siswa di SDN Sukodono 03 masih rendah, diantaranya siswa yang terlambat datang ke sekolah, lupa mengerjakan tugas rumah, ramai di kelas sehingga pembelajaran berjalan tidak kondusif, melanggar tata tertib sekolah antara lain membuang sampah sembarangan, tidak memakai topi saat upacara, dll. Berdasarkan hasil observasi lembar kedisiplinan pra siklus, menunjukkan bahwa 100\% siswa kurang disiplin dalam segala aspek. Menurut (Budiono, 2017 : 4) Disiplin adalah sikap kepatuhan siswa dalam mengikuti peraturan yang didorong oleh kesadaran dari dalam diri. Disiplin adalah perilaku yang dilakukan sesuai dengan ketetapan, siswa yang disiplin memiliki peluang yang lebih besar untuk mendapat nilai belajar yang tinggi. Christina dan Kristin (2016: 223) Hasil belajar merupakan perubahan perilaku siswa setelah mengikuti pelajaran terjadi akibat lingkungan belajar yang sengaja dibuat oleh guru melalui model pembelajaran yang dipilih dan digunaka dalam suatu pembelajaran. 
S. Prayogo, F. Kristin, I. Anugraheni | JPDP 5 (2) Oktober 2019, 121-132

Pada era sekarang di tingkat sekolah dasar pembelajaran dan sikap kedisiplinan dalam meningkatkan hasil belajar sangatlah kurang. Keadaan ini dilihat dari masih banyaknya siswa yang belum tuntas KKM pada mata pelajaran PKn SD. Berdasarkan hasil data nilai siswa, masih banyak siswa yang berada di bawah nilai KKM (70), dari 23 siswa sebanyak 16 siswa atau 71,4\% masih kurang dari KKM (70).

Penyebab siswa belum tuntas KKM diduga karena masih kurangnya alat peraga atau media pembelajaran yang menarik perhatian siswa, rendahnya minat baca siswa, kurangnya perhatian siswa ketika pembelajaran berlangsung, pendekatan yang dilakukan guru kurang sesuai, kurang aktifnya siswa yang terlibat dalam pembelajaran, kurangnya contoh dan latihan. Untuk menanggulangi hal tersebut guru memiliki peran yang penting. Hal ini dapat diselesaikan oleh berbagai model pembelajaran yang ada di berbagi bidang pendidikan yang ada di Indonesia.

Model pembelajaran reflektif merupakan model pembelajaran untuk mencapai tujauan dengan merefleksikan hasil belajar yang ada. Kemampuan reflektif memungkinkan siswa merefleksikan materi yang sudah diajarkan dan mengambil hikmah, sehingga dapat mempermudah penerapan dalam kehidupan sehari-hari Ingridwati (2011: 125). Oleh karena itu, peneliti menerapkan model pembelajaran Reflektive Learning dalam muatan pembelajaran PKn pada Tema 1 Subtema 2 kelas 5 SDN Sukodono 03 Kab,Jepara bertujuan untuk meningkatkan kedisiplinan dan hasil belajar mapel PKn siswa. Model pembelajaran Reflektive Learning di pilih karena dengan pertimbangan semua orang pasti belajar dari pengalaman. Refleksi ialah bentuk awal belajar siswa secara mandiri untuk mengetahui pemahaman awal dan rencana yang dikerjakan selanjutnya. Rencana yang telah dibuat atau yang telah dipikirkan siswa merupakan bentuk kemandirian siswa yang dapat memicu kreatifvitas siswa sehingga proses pembelajaran menjadi aktif. Siswa tidak selalu menunggu intruksi dari guru untuk belajar. Hasil penelitian yang dilakukan oleh Loo dan Thorpe dalam Merriam (2015 : 93) menyatakan 
S. Prayogo, F. Kristin, I. Anugraheni | JPDP 5 (2) Oktober 2019, 121-132

bahwa pembelajaran reflektive dapat berlangsung efektif pada pembelajaran mandiri dan kelompok.

Maka untuk mengetahui peningkatan kedisplinan dan hasil belajar muatan pembelajaran $\mathrm{PKn}$ siswa dilakukanlah penelitian yang bertujuan untuk mengetahui langkahlangkah dari model Reflektive Learning dalam meningkatkan kedisiplinan dan hasil belajar mapel PKn siswa di kelas 5 SD Negeri Sukodono, Kab. Jepara.

\section{Metode}

Jenis penlitian ini adalah Penelitian Tindakan Kelas (PTK). Penelitian dilakukan di SDN Sukodono 03 kecamatan Tahunan, kota Jepara. Subyek penelitian ini adalah siswasiswi kelas 5 SDN Sukodono 03 yaitu sebanyak 23 siswa. Menurut Suharsimi Arikunto (2010) penelitian tindakan kelas dilakukan sekurangkurangnya dalam dua siklus tindakan yang berurutan yaitu (1) perencanaan, (2) pelaksanaan, (3) pengamatan dan (4) refleksi. Penelitian ini dialakukan dalam dua siklus, satu siklus tiga kali pertemuan setiap pertemuan $4 \times 35$ menit.
Teknik pengumpulan data yang diguanakan adalah tes dan non tes. Teknit tes tertulis berbentuk soal pilihan ganda yang digunakan dalam mengukur hasil belajar siswa mapel PKn tema 1 subtema 2 . Teknik non tes di dapat dari lembar observasi yang dilakuakn oleh observer di gunakan untuk mengukur kedisiplinan siswa. Sedangkan teknik analisis data menggunakan yang berupa data statistik deskriptif kualitatif dan kuantitatif. Hasil belajar siswa diukur melalui nilai yang di dapat siswa pada evaluai siklus 1 dan siklus 2, dan di nyatakan meningkat apabila diatas $70 \%$ siswa memperoleh hasil diatas KKM sebesar 60 sesuai dengan ketentuan SDN Sukodono 03.

\section{Hasil dan Pembahasan}

Penelitian ini dilaksanakan dalam 2 siklus yang terdiri masingmasing 3 pertemuan $4 \times 35$ menit. Keseluruhan pertemuan dalam penelitian ini berjumlah 6 kali pertemuan. Di bawah ini adalah hasil observasi berupa tabel observasi kedisiplinan siswa mapel PKn Tema 1 Sub tema 2 dari kondisi awal atau pra siklus, siklus 1, dan siklus 2 siswa $\begin{array}{lllll}\text { kelas } & 5 & \text { SDN } & \text { Sukodono } & 03\end{array}$ 
S. Prayogo, F. Kristin, I. Anugraheni | JPDP 5 (2) Oktober 2019, 121-132

menggunakan model pembelajaran dengan audio visual.

Reflektive Learning berbantuan

Tabel 1. Peningkatan Kedisiplinan Siswa

\begin{tabular}{|c|c|c|c|c|c|c|c|}
\hline \multirow[t]{2}{*}{ Skala } & \multirow[t]{2}{*}{ Kriteria } & \multicolumn{2}{|c|}{ Pra Siklus } & \multicolumn{2}{|c|}{ Siklus 1} & \multicolumn{2}{|c|}{ Siklus 2} \\
\hline & & frekuensi & $\%$ & frekuensi & $\%$ & Frekuensi & $\%$ \\
\hline $\begin{array}{l}90- \\
100\end{array}$ & $\begin{array}{c}\text { Sangat } \\
\text { Disiplin }\end{array}$ & 0 & 0 & 9 & 49,13 & 23 & 100 \\
\hline $80-89$ & Disiplin & 0 & 0 & 14 & 60,87 & 0 & 0 \\
\hline $65-79$ & $\begin{array}{l}\text { Cukup } \\
\text { Disiplin }\end{array}$ & 0 & 0 & 0 & 0 & 0 & 0 \\
\hline $55-64$ & $\begin{array}{l}\text { Kurang } \\
\text { Disiplin }\end{array}$ & 23 & 100 & 0 & 0 & 0 & 0 \\
\hline \multicolumn{2}{|c|}{ Jumlah } & 23 & $100 \%$ & 23 & 100 & 23 & 100 \\
\hline \multicolumn{2}{|c|}{ Rata-rata } & \multicolumn{2}{|c|}{50,43} & \multicolumn{2}{|c|}{88,40} & \multicolumn{2}{|c|}{96,73} \\
\hline \multicolumn{2}{|c|}{ Kriteria } & \multicolumn{2}{|c|}{ Kurang Disiplin } & \multicolumn{2}{|c|}{ Disiplin } & \multicolumn{2}{|c|}{ Sangat Disiplin } \\
\hline
\end{tabular}

Berdasarkan tabel 1 dapat kedisiplinan siswa pada setiap dilihat yang menunjukkan hasil yaitu siklusnya, hal ini dibuktikan dengan terjadi peningkatan pada tahap pra perolehan persentase dalam setiap siklus ke siklus 1 ke siklus 2 terhadap kedisiplinan siswa pada saat proses pembelajaran dengan penerapan model pembelajaran Reflektive Learning berbantuan dengan media audio visual. Hasil data diperoleh melalui hasil observasi pada proses pembelajaran dan dengan menghitung seluruh indikator kedisiplinan siswa. Dapat diketahui dengan menerapkan model pembelajaran Reflektive Learning berbantuan dengan media audio visual dapat meningkatkan aspek kedisiplinan yang mengalami peningkatan yang signifikan. Persentase kedisiplinan siswa berada pada kategori sangat disiplin dan disiplin yang terjadi pada pra siklus $0 \%$ dan $0 \%$ meningkat pada siklus 1 menjadi 39,13\% dan 60,87\% serta pada tindakan siklus 2 meningkat menjadi 100\% siswa dengan kriteria sangat disiplin. Skor rata-rata yang didapat pada pra siklus 50,43 yang berada pada kurang disiplin, kemudian setelah melakukan tindakan 
S. Prayogo, F. Kristin, I. Anugraheni | JPDP 5 (2) Oktober 2019, 121-132

siklus 1 meningkat menjadi 88,40 berada pada kategori disiplin dan pada tindakan siklus 2 meningkat menjadi 96,73 berada pada kategori sangat disiplin. Setelah dilakukannya tindakan siklus 2 menunjukkan kedisiplinan mencapai harapan yaitu mencapai $80 \%$ dari jumlah keseluruhan siswa dengan memperoleh skor rata-rata 96,73 berada pada kategori sangat disiplin dan jumlah siswa yang memiliki kategori baik dan sangat baik dengan mencapai persentase $100 \%$. Dismpulkan bahwa kedisiplinan siswa meningkat secara signifikan dari pra siklus, siklus pada muatan pembelajaran PKn siswa kelas 5 SDN Sukodono 03. Sedangkan peningkatan hasil belajar siswa kelas 5 SDN Sukodono 03 muatan pelajaran PKn dapat dilihat dari tabel berikut :

Tabel 2. Peningkatan Hasil Belajar

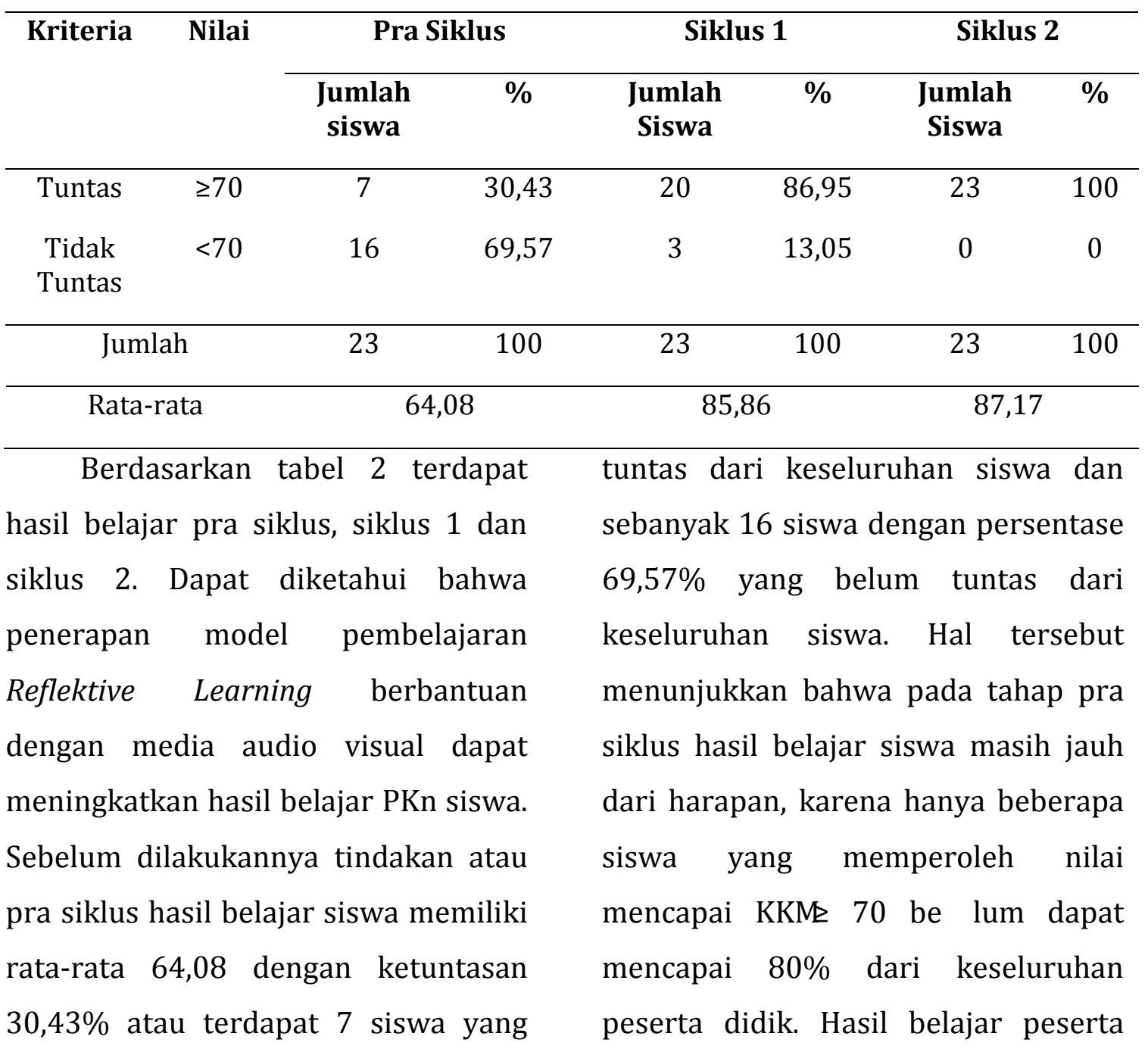


S. Prayogo, F. Kristin, I. Anugraheni | JPDP 5 (2) Oktober 2019, 121-132

didik mengalami peningkatan setelah dilakukannya tindakan kelas dengan menerapkan model pembelajaran Reflektive Learning berbantuan dengan media audio visual. Pada siklus 1 pada hasil belajar mengalami peningkatan yang signifikan. Rata-rata hasil belajar siswa meningkat menjadi 85,86 sebanyak 20 siswa dengan persentase $\quad 86,95 \%$ yang sudah mendapatkan nilai tuntas dan sebanyak 3 siswa dengan persentase $13,05 \%$ yang belum mendapatkan nilai tuntas . Hasil ketuntasan belajar siswa mengalami peningkatan kembali setelah dilakukannya tindakan siklus 2. Rata-rata hasil belajar peserta didik mengalami peningkatan hasil belajar PKn sebesar 13,05\% menjadi 87,17 sebanyak 23 peserta didik dengan persentase $100 \%$ yang telah mencapai nilai ketuntasan. Setelah dilakukannya tindakan siklus 2 menunjukkan persentase ketuntasan hasil belajar siswa yang sudah mencapai harapan yaitu mencapai $80 \%$ dari jumlah keseluruhan siswa yang memperoleh nilai mencapai $\mathrm{KKM} \geq 70$.

Berdasarkan pada data kedisiplinan siswa dan hasil belajar mata pelajaran PKn yang telah dipaparkan diatas, maka diperoleh hasil bahwa terjadi peningkatan pada penerapan model pembelajaran Reflektive Learning berbantuan dengan media audio visual terhadap kedisiplinan siswa dan hasil belajar mata pelajaran PKn bagi peserta siswa V SD Negeri Sukodono 03. Hasil penelitian menunjukkan, terjadi peningkatan kedisiplinan dan hasil belajar siswa ini dibuktikan dengan peningkatan persentase kedisiplinan siswa pada siklus 1 ke siklus 2. Pada pra siklus memperoleh rata-rata skor sebesar 50,43 yang berada pada kategori kurang disiplin, kemudian meningkat pada siklus 1 menjadi 88,40 sudah berada pada kategori disiplin dan pada siklus 2 meningkat menjadi 96,73 terjadi peningkatan sebesar 8,33 dengan berada pada kategori sangat disiplin . Hal ini senanda dengan penelitian yang dilakukan oleh Senada dengan itu Penelitian yang dilakukan oleh Yudha Mahardika (2013 : 71) dalam skripsinya yang berjudul "Upaya Peningkatan Aktivitas Belajar Peserta Didik Kelas V dengan Model Reflektive Learning di SDN 1 Godean Tahun Ajaran 2012/2013" menyimpulkan bahwa terjadi peningkatan aktivitas 
S. Prayogo, F. Kristin, I. Anugraheni | JPDP 5 (2) Oktober 2019, 121-132

belajar siswa Kelas V SDN 1 Godean tahun ajaran 2012/2013 setelah menggunakan model Reflektif Learning Hal ini dibuktikan pada ratarata aktivitas belajar peserta didik pada siklus I menunjukkan 75,52\%. Sedangkan hasil presentase capaian untuk siklus ke II naik menjadi $94,70 \%$ dengan memeperoleh peningkatan sebesar 19,18\%.

Ketuntasan hasil belajar siswa dari sebelum diberikan tindakan kelas dari pra siklus ke siklus 1 besarnya peningkatan adalah 30,43\% menjadi $86,95 \%$. Dari hasil pada siklus 1 menunjukkan bahwa tindakan pada siklus 1 memiliki pengaruh terhadap hasil belajar pada mata pelajaran PKn di SD Negeri Sukodono 03, peningkatan tersebut bisa dikatakan berhasil. Hal ini dikarenakan persentase peserta yang mencapai KKM sudal $80 \%$ sesuai dengan indikator keberhasilan yang telah ditentukan. Kemudian terdapat peningkatan kembali dari siklus 1 ke siklus 2 adalah dari 86,95\% menjadi 100\%. Pada siklus 2 jumlah siswa yang tuntas atau yang lebih dari KKM terdapat sebanyak 23 peserta didik atau sebesar 100\%. Sependapat dengan penelitian yang dilakukan oleh
Surprianto (2013) melakukan penelitian yang berjudul "Penerapan Metode Pembelajaran Student Teams Achievement Devision (STAD) untuk meningkatkan kedisiplinan dan hasil belajar Siswa kelas V SD 06 Sukowono Jember pada pembelajaran PKn menggunakan metode kooperatife tipe STAD". Presentasi klasikal hasil belajar siswa dari pra-siklus $(53,3 \%)$, meningkat pada siklus $1(62,5 \%)$ dan siklus $2(87,5 \%)$. dan siklus 2.

Jika dibandingkan dengan indikator keberhasilan yang sudah ditetapkan, maka penelitian ini dapat dikatakan berhasil karena hasil penelitian tersebut telah melebihi indikator keberhasilan yang telah ditentukan dalam penelitian yaitu 80\% dari jumlah keseluruhan peserta didik yang telah mendapat nilai diatas KKM $\geq 70$. Penerapan model Reflektive Learning pada siswa kelas 5 SDN Sukodono 03 dapat meningkatkan kedisiplinan dan hasil belajar siswa mapel PKn pada Tema 1 Sub Tema 2. Pada penelitian ini terjadi peningkatan dari kondisi awal atau pra siklus, siklus 1 sampai siklus 2 yang meningkat setelah di terapkannya model pembelajaran Reflektive Learning berbantuan 
S. Prayogo, F. Kristin, I. Anugraheni | JPDP 5 (2) Oktober 2019, 121-132

dengan media audio visual sangat bepengaruh pada peningkatan hasil belajar. Hal ini sesuai dengan teori Mustari (2014 : 56) berpendapat bahwa disiplin merujuk pada instruksi sitematis yang diberikan kepada murid. Untuk mendisiplinkan berarti menginstruksikan orang untuk mengikuti tatanan tertentu melalui aturan-aturan tertentu. Sehingga dapat disimpulkan bahwa meningkatnya kedisiplinan siswa juga dapat berpengaruh pada hasil belajar siswa.yang meningkat secara signifikan. Hasil penelitian ini juga selaras dengan teori yang dikemukakan oleh Kristin (2016:78) bahwa hasil belajar adalah hasil yang diperoleh akibat dari suatu aktivitas yang dilakukan dan mengakibatkan terjadinya perubahan tingkah laku.

Keunggulan dari penelitian ini adalah, penerapan model pembelajaran Reflektive Learning sangat mudah diterapkan di siswa dengan langkah-langkah yang cukup mudah diingat. Sehingga guru dapat memahami dan menyampaikan materi dengan mudah. Dibantu dengan media audio visual yang dapat membangkitkan siswa untuk belajar secara aktif, sehingga kedisiplianan dan hasil belajar siswa maningkat secara signifikan

\section{Simpulan}

Penelilitan yang telah dilaksankan dari siklus I sampai dengan siklus II diperoleh hasil data yang dapat disimpulkan dengan sebagai berikut:

Pada penerapan model pembelajaran Reflektive Learning berbantuan dengan media audio visual siswa kelas 5 SD Negeri Sukodono 03 dengan melalui langkahlangkah menurut Dewey dalam Ningsih dan Rohana (2012 : 146) yaitu: a. Memahami masalah, b.merumuskan masalah c.menentukan penyelesaian masalah, d.mencari hubungan, e.merumuskan hipotesis, f.Membuktikan Hipotesis dan g. evaluasi . terbukti secara signifikan dapat meningkatkan kedisiplinan dan hasil belajar siswa mapel PKn semester 1 tema 1 sub tema 2 .

Penerapan model pembelajaran Reflektive Learning berbantuan dengan media audio visual siswa kelas 5 SD Negeri Sukodono 03 tahun ajaran 2019/2020 meningkatkan kedisiplinanan siswa. Hal ini dapat ditunjukkan melalui perolehan 
S. Prayogo, F. Kristin, I. Anugraheni | JPDP 5 (2) Oktober 2019, 121-132

Persentase kedisiplinan siswa berada pada kategori sangat disiplin dan disiplin yang terjadi pada pra siklus $0 \%$ dan $0 \%$ meningkat pada siklus 1 menjadi $39,13 \%$ dan $60,87 \%$ serta pada tindakan siklus 2 meningkat menjadi $100 \%$ siswa dengan kriteria sangat disiplin. Skor rata-rata yang didapat pada pra siklus 50,43 yang berada pada kurang disiplin, kemudian setelah melakukan tindakan siklus 1 meningkat menjadi 88,40 berada pada kategori disiplin dan pada tindakan siklus 2 meningkat menjadi 96,73 berada pada kategori sangat disiplin. Setelah dilakukannya tindakan siklus 2 menunjukkan kedisiplinan mencapai harapan yaitu mencapai $\quad 80 \%$ dari jumlah keseluruhan siswa dengan memperoleh skor rata-rata 96,73 berada pada kategori sangat disiplin dan jumlah siswa yang memiliki kategori baik dan sangat baik dengan mencapai persentase 100\%.

Penerapan model pembelajaran Reflektive Learning berbantuan dengan media audio visual siswa kelas 5 SD Negeri Sukodono 03 tahun ajaran 2019/2020 meningkatkan hasil belajar siswa mapel PKn tema 1 sub tema 2. Hal ini dapat ditunjukkan melalui perolehan pra siklus hasil belajar siswa memiliki rata-rata 64,08 dengan ketuntasan 30,43\% atau terdapat 7 siswa yang tuntas dari keseluruhan siswa dan sebanyak 16 siswa dengan persentase 69,57\% yang belum tuntas dari keseluruhan siswa Hal tersebut menunjukkan bahwa pada tahap pra siklus hasil belajar siswa masih jauh dari harapan, karena hanya beberapa siswa yang memperoleh nilai mencapai $\mathrm{KKM} \geq 70$ belum dapat mencapai $80 \%$ dari keseluruhan peserta didik. Hasil belajar peserta didik mengalami peningkatan setelah dilakukannya tindakan kelas dengan menerapkan model pembelajaran Reflektive Learning berbantuan dengan media audio visual. Pada siklus 1 pada hasil belajar mengalami peningkatan yang signifikan. Rata-rata hasil belajar siswa meningkat menjadi 85,86 sebanyak 20 siswa dengan persentase $86,95 \%$ yang sudah mendapatkan nilai tuntas dan sebanyak 3 siswa dengan persentase $13,05 \%$ yang belum mendapatkan nilai tuntas.

Hasil ketuntasan belajar peserta didik mengalami peningkatan kembali setelah dilakukannya tindakan siklus 2. Rata-rata hasil belajar peserta didik 
S. Prayogo, F. Kristin, I. Anugraheni | JPDP 5 (2) Oktober 2019, 121-132

mengalami peningkatan menjadi 87,17 sebanyak 23 peserta didik dengan persentase $100 \%$ yang telah mencapai nilai ketuntasan. Setelah dilakukannya tindakan siklus 2 menunjukkan persentase ketuntasan hasil belajar peserta didik yang sudah mencapai harapan yaitu mencapai 80\% dari jumlah keseluruhan peserta didik yang memperoleh nilai mencapai $\mathrm{KKM} \geq 70$.

\section{Daftar Pustaka}

Anugraheni, I. (2017). Penggunaan Portofolio dalam Perkuliahan Pembelajaran. Jurnal Pendidikan Dasar Perkhasa, 246-258.

Budiono. (2017). Pengembangan Pendidikan Karakter. Semarang: Refika Aditama.

Cintia, N. I., Kristin, F., \& Anugraheni, I. (2018). Penerapan Model Pembelajaran Discovery Learning untuk Meningkatkan Kemampuan Berpikir Kreatif dan Hasil belajar Siswa. Perspektif IImu Pendidikan, 32(1), 67-75.

Hadianti, L. S. (2017). Pengaruh Pelaksanaan Tata Tertib Sekolah Terhadap Kedisiplinan Belajar Siswa (Penelitian Deskriftif
Analisis di SDN Sukakarya II Kecamatan samarang Kabupaten Garut). Jurnal Pendidikan UNIGA, 2(1), 1-8.

Karoni. (2011). Pembelajaran Reflektive Learning untuk meningkatkan keaktifan bertanya siswa dalam pembelajaran PKn kelas IV MIM Sraten, Kecamatan Galak, Kabupaten, Sukoharjo Tahun Ajaran 2010/2011. Mimbar PGSD, 56.

Kristin, F. (2016). Efektivitas Model Pembelajaran Kooperatif Tipe STAD Ditinjau dari Hasil Belajar IPS Siswa Kelas 4 SD. Scholaria:Jurnal Pendidikan dan Kebudayaan, 74-79.

Mahardika, Y. (2012). Upaya Peningkatan Aktivitas Belajar Peserta Didik Kelas V dengan Model Reflektive Learning di SDN 1 Godean Tahun Ajaran 2012/2013. Pendidikan Sekolah Dasar, 25.

Muntiah. (2010). Desain Pembelajaran . Tasik Malaya: Bumi Aksara.

Soemantri. (2011). Pendidikan Kewarganegaraan. Yogyakarta: Reka Karya group. 
S. Prayogo, F. Kristin, I. Anugraheni | JPDP 5 (2) Oktober 2019, 121-132

Sumantri, B. (2010). Pengaruh disiplin belajar terhadap prestasi belajar siswa kelas V SD Pgri 4 Ngawi Tahun

$$
\text { Pelajaran }
$$
2009/2010. Media Prestasi, 6(3), 117-131.

Suprianto. (2013). Penerapan Metode Pembelajaran Student Teams Achievement Devision (STAD) untuk meningkatkan kedisiplinan dan hasil belajar Siswa kelas V SD 06 Sukowono Jember pada pembelajaran PKn menggunakan metode kooperatife tipe STAD. Pedidikan Berkelanjutan, 54.

Trianto. (2011). Model Asesmen Pembelajaran. Jakarta: Kencana Media Group. 